identified: he performs both psychological and pedagogical correction. The specifics of the corrective-developmental activity of the future speech therapist are revealed. The speech, the formed communicative competence are the tools of corrective influence on them, their parents, colleagues, administration. We indicated the areas of knowledge, and skills in which students should be competent: they perform educational, corrective, compensatory, and rehabilitation work with children with speech disorders; provide conditions for learning disability compensation and corrective programs taking into account disabilities, age and individual peculiarities; promote social rehabilitation, vocational guidance; study and record the dynamics of the child's development; create favorable organizational and pedagogical conditions for children with severe speech disorders (with rhinolalia, stuttering, alalia, aphasia, dysarthria); produce the optimal pedagogical and corrective strategy, etc. Features of professional activity of the future speech therapist are distinguished: polyfunctionality, multidimensionality (internal and semantic integration), diversity (external and institutional integration), versatility (has multiple manifestations in the system) of the speech therapist's functions.

Key words features, professional training, future speech therapists, higher education institutions, professional activity.

УДк 378.018.8:373.5.011.3-051:364-786

\author{
Анна Чередник \\ Уманський державний педагогічний \\ університет імені Павла Тичини \\ ORCID ID 0000-0002-8021-4708
}

DOI 10.24139/2312-5993/2019.07/037-047

\title{
ПІДГОТОВКА МАЙБУТНІХ УЧИТЕЛІВ-РЕАБІЛІТОЛОГІВ ДО РОБОТИ В УМОВАХ ІНКЛЮЗИВНОГО НАВЧАННЯ УЧНІВ: КАТЕГОРІАЛЬНИЙ АПАРАТ
}

У статті здійснено спробу уточнити категоріальний апарат дослідження. На основі аналізу понять «інвалідність», «непрацездатність», «особливі потреби дітей», «порушення розвитку», «дезадаптація», «діти групи ризику», «проблемні діти», «діти з аномальним розвитком», «діти з інвалідністю», «діти з обмеженими можливостями», «особливі діти», «виняткові діти» уточнено терміни «діти 3 особливими освітніми потребами», «інклюзивне навчання». Для розкриття ключового поняття «підготовка майбутніх учителів-реабілітологів до роботи в умовах інклюзивного навчання учнів загальноосвітніх навчальних закладів» розкрито сутність дотичних понять: «корекційно-педагогічна діяльність», «реабілітаційнопедагогічна діяльність».

Ключові слова: дезадаптація, діти групи ризику, діти з інвалідністю, діти з обмеженими можливостями, діти з особливими освітніми потребами, інклюзивне навчання, підготовка майбутніх учителів-реабілітологів.

Постановка проблеми. У будь-якому суспільстві $€$ люди, які мають відхилення у фізичному, психічному або соціальному розвитку. Це означає, що зовнішні обставини, у яких знаходиться людина, або стан ії̈ здоров'я не відповідають певним, прийнятим у даному суспільстві нормам. 
Сфера нормального завжди має в свідомості людей свої межі, а все те, що знаходиться за їх межами, визначається як «ненормальне», «патологічне» (Шумиловская, 2011).

Ненормативний розвиток - явище складної природи. На рівні організму, на ґрунті незрілості фізіологічних систем спостерігається недорозвинення (або надрозвинення) функцій психіки. На рівні індивіда на перший план виступає соціальна ситуація розвитку дитини, яка сприяє формуванню ненормативних властивостей характеру. На рівні особистості, де діють психологічні чинники, ненормативний психічний розвиток проявляється у вчинку, який може здійснювати егоцентрична особистість (Глушко, 2004).

Реалії сучасного життя свідчать, що в будь-якому суспільстві $є$ люди, які потребують особливої уваги до себе за наявних будь-яких відхилень (ненормативних) у фізичному, психічному або соціальному розвитку.

Аналіз актуальних досліджень. Проблеми диференціації дітей із особливими освітніми потребами на групи, рівні шкільної дезадаптації, а відповідно поняттєвий апарат досліджували Л. Байда, Т. Власова, Г. Давиденко, Е. Даніельс, Т.Ілляшенко, А. Колупаєва, Е. Кулакова, В. Лебединський, В. Липа, М. Любимов, О. Нагорна, Т. Окушко, Н. Софій, О. Усанова, О.Чеботарьова. Науковці розкрили поняття «інвалідність», «непрацездатність», «особливі потреби дітей», «порушення розвитку», «дезадаптація», «діти групи ризику», «проблемні діти», «діти 3 аномальним розвитком», «діти 3 інвалідністю», «діти 3 обмеженими можливостями», «особливі діти», «виняткові діти» та ін. У межах нашого дослідження актуальними $€$ поняття «діти 3 особливими освітніми потребами», «інклюзивне навчання».

Мета статті - на основі аналізу дотичних термінів уточнити сутність ключових понять «діти з особливими освітніми потребами», «інклюзивне навчання», «підготовка майбутніх учителів-реабілітологів до роботи в умовах інклюзивного навчання учнів загальноосвітніх навчальних закладів».

Методи дослідження - теоретичні - аналіз наукових джерел із проблеми дослідження, що дало змогу визначити мету, уточнити сутність ключових понять «діти з особливими освітніми потребами», «інклюзивне навчання», «підготовка майбутніх учителів-реабілітологів до роботи в умовах інклюзивного навчання учнів загальноосвітніх навчальних закладів».

Виклад основного матеріалу. До 70-х років XX століття в термінології існувала плутанина у використанні термінів «інвалідність» і «непрацездатність», що перешкоджало розробці відповідної політики у відношенні цілісної популяції людей, які потребують реабілітації. 1980 рік ознаменувався прийняттям класифікації дефектів, інвалідності та непрацездатності (Восстановление трудоспособности, 1969). 
у 1986 році Міжнародна асоціація інвалідів приймає інтегральне визначення поняття «інвалідність», у якому знайшли відображення обидва аспекти: медичний та соціальний. Інвалідність - це обумовлена фізичними бар'єрами втрата або обмеження можливостей участі в житті суспільства нарівні з іншими умовами. Не інваліди $\epsilon$ проблемою для суспільства, навпаки, суспільство не хоче або не вміє зняти бар'єри на шляху возз'єднання суспільства та інвалідів шляхом створення відповідних умов для останніх (Тимофеева, 2004, 76).

Основою визначення «інвалідності» $\epsilon$ поняття «обмеження життєдіяльності». Відповідно до Міжнародної номенклатури порушень, «під обмеженням життєдіяльності» розуміється будь-яке обмеження або відсутність здатності здійснювати діяльність способом в рамках, що вважається нормальним для людини даного віку (Реабилитация, 1997).

Найбільш поширене та прийнятне стандартне визначення «особливих потреб», зокрема в країнах Європейської Спільноти, подано в Міжнародній класифікації стандартів освіти (International Standart Classification of Education): особливі освітні потреби мають особи, навчання яких потребує додаткових ресурсів. Додатковими ресурсами можуть бути: персонал (для надання допомоги у процесі навчання); матеріали (різноманітні засоби навчання, зокрема допоміжні та корекційні); фінансові (бюджетні асигнування для одержання додаткових спеціальних послуг) (Колупаєва та Савчук, 2011).

Одним із центральних понять реабілітаційної педагогіки в розгляді проблем, які потребують педагогічної реабілітації дітей, $\epsilon$ поняття «дезадаптація». Термін «дезадаптація» з'явився у психіатричній літературі і позначає порушення процесу взаємодії людини 3 навколишнім середовищем.

На думку А.Гордєєвої, саме діти з порушеннями середовищної адаптації в первинному навчальному колективі і повинні розглядатися як основний об'єкт педагогічної реабілітації, щодо якої школа несе всю повноту відповідальності (Гордеева, 2002, с. 69).

Постійна ситуація неуспіху, конфлікти між учителем і учнем, учнем і учнем, вікові кризи, що накладаються на це, через які проходить зростаюча особистість, призводять швидше до десоціалізації, реалізації себе не в конструктивній, а деструктивної діяльності, схильності неформальним впливам, небезпечним для фізичного і психічного здоров'я (наркоманія, проституція, правопорушення, релігійні секти тощо) (Федина, 2002).

До числа основних первинних зовнішніх ознак шкільної дезадаптації і лікарі, і педагоги, і психологи одностайно відносять утруднення в навчанні і різні порушення шкільних норм поведінки.

Поняття «діти з обмеженими можливостями» робить акцент саме на соціальній складовій інвалідності, на здатності до соціалізації, а 
«обмежувачем» їх можливостей вважається тільки сучасний суспільний устрій, у якому потенціал таких дітей не затребуваний у силу їх специфічності. Діти з обмеженими можливостями, безумовно, відчувають труднощі не тільки внаслідок захворювання, що призвело до відхилення, але й за непристосованості фізичного і соціального оточення до їхніх потреб, неприйняття суспільством. У більшості таких дітей порушений зв'язок із зовнішнім світом, обмежена мобільність, незначні контакти з однолітками і дорослими, зменшене спілкування з природою, культурою, часто відсутні можливості отримувати навіть елементарну освіту (Городова, 2011, с. 22).

На зміну принижуючим гідність термінам «інваліди», «аномальні діти», «діти з відхиленнями в розвитку» приходять нові, зокрема діти 3 обмеженими можливостями здоров'я. Це діти, стан здоров'я яких перешкоджає освоєнню освітніх програм без створення спеціальних умов навчання (виховання) - діти з інвалідністю, а також інші діти віком від 0 до 18 років, не визнані в установленому порядку дітьми з інвалідністю, але які мають тимчасові або постійні відхилення у фізичному і (або) психічному розвитку й потребують створення спеціальних умов навчання (виховання) (діти з порушеннями слуху, зору, опорно-рухового апарату, мови, інтелекту, іншими захворюваннями) (Хафизуллина, 2008, с. 15).

Поняття «діти з особливими освітніми потребами» широко охоплює всіх учнів, чиї освітні проблеми виходять за межі загальноприйнятої норми. Воно стосується дітей із особливостями психофізичного розвитку, обдарованих дітей та дітей із соціально вразливих груп (наприклад, вихованців дитячих будинків тощо). Загальноприйнятий термін «діти 3 особливими освітніми потребами» робить наголос на необхідності забезпечення додаткової підтримки в навчанні дітей, які мають певні особливості розвитку. Вочевидь, прийнятним $є$ визначення, за яким до дітей із особливими потребами відносять дітей з інвалідністю, дітей з незначними порушеннями здоров'я, соціальними проблемами та обдарованих дітей (Колупаєва та Савчук, 2011, с. 36).

На нашу думку, «діти з особливими освітніми потребами» - це діти 3 відхиленням у розвитку, унаслідок якого відбувається обмеження можливостей їх участі в традиційному освітньому процесі, що викликає в них особливі потреби в спеціалізованій педагогічній допомозі, яка дозволяє долати ці обмеження, труднощі.

Еволюція ідей реабілітації пройшла кілька етапів і в минулому була пов'язана з благодійною діяльністю. Тільки в XX столітті концепція благодійності поступилася місцем спочатку ідеям надання соціальної підтримки, а потім і принципам реабілітації зі створення умов для вільної й незалежної життєдіяльності людей з інвалідністю (Гарашкина, 2006, с. 27).

Науковці доводять, що центральним у категоріальному апараті реабілітаційної педагогіки є поняття «реабілітація». 
Пізньолатинське rehabilitatio - відновлення - сходить до habilitas придатність, здатність; re - приставка - висловлює (в даному випадку) відновлення, повторення. Це означає, реабілітувати - дослівно - зробити знову здатним, знову придатним, слова «здатність» і «придатність» характеризують реабілітацію спочатку як соціально спрямований процес, який має на меті соціалізацію та адаптацію людини. Здібності, необхідні для повноцінної участі в житті суспільства, визначаються самим соціумом, його розвитком. Тоді не здатність (непридатність) - породжує стрес, активує страх, створює ситуацію, коли людина відчуває власну неповноцінність - дезадаптацію (Федина, 2002, с. 15).

Всесвітня організація охорони здоров'я вважає, що сутність реабілітації полягає в тому, щоб «не тільки повернути хворого до його попереднього стану, а й розвивати його фізичні та психологічні функції до оптимального рівня» (Восстановление трудоспособности, 1969, с. 255).

Реабілітація неможлива без відновлення дитини у статусі i дієздатності. У психолого-педагогічному сенсі це означає відновлення дитини як соціального суб'єкта провідної діяльності. Реабілітація пов'язана не тільки з подоланням сімейних, шкільних утруднень і соціальної дискримінації неповнолітніх, але також зі зміною уявлень дитини про себе іï Я-концепції. Виходячи з цілісного розуміння дитини, реабілітація дитини здійснюється на рівні особи, суб'єкта діяльності і соціального суб'єкта 3 урахуванням ії індивідуальності (Фабро, 2010, с. 106).

У найбільш загальному трактуванні, реабілітація охоплює динамічну систему взаємопов'язаних медичних, психологічних і соціальних складових, які спрямовані не лише на відновлення та збереження здоров'я та соціального статусу особистості в соціумі. Реабілітацію Ю. Бриндіков розглядає в якості окремого виду соціальної діяльності спеціально уповноважених органів держави, соціальних служб, об'єднань громадян та інших соціальних інститутів, яка безпосередньо спрямована на здійснення організаційних, економічних, правових, культурних, освітніх, лікувальних, оздоровчих та інших соціальних заходів щодо відновлення фізичного стану, честі, гідності, прав і свобод певних категорій населення (Бриндіков, 2017, с. 107).

Таким чином, процес реабілітації визначається по суті як комплексний, що включає медичні, психологічні та соціально-економічні заходи.

Нам імпонує трактування поняття «реабілітація», подане у словнику термінів для спеціалістів у галузі реабілітації хворих та інвалідів, у якому під цим терміном розуміють процес і систему медичних, психологічних, педагогічних і соціально-економічних заходів, спрямованих на усунення або можливо більш повну компенсацію обмежень життєдіяльності, викликаних порушенням здоров'я зі стійким розладом функцій організму (Реабилитация, 1997, с. 58). 
Ефективність реабілітації оцінюється на основі повного надання всього спектру реабілітаційних заходів (медичних, соціальних, психологічних, педагогічних, професійних). До розладів, які спричиняють необхідність реабілітації науковці відносять: інвалідність, захворювання на алкоголізм, наркозалежність, втрату соціального статусу, роботи, житла, близьких людей, скоєння злочинів (Єжова, 2013, с. 109).

Л. Федина розглядає «реабілітаційну діяльність» як діяльність педагога, спрямовану на надання допомоги дитині в знятті стану дезадаптації і подолання ії̈ власних бар'єрів, що є причиною дискомфортності діяльності й низької результативності, а також у підтримці та розвитку в неї самоповаги і віри в свої сили (Федина, 2002, с. 19).

Близьким за сутністю $є$ поняття «корекційно-педагогічна діяльність», яке А.Гонєєв визначає як складне соціально-педагогічне явище, що пронизує весь освітній процес (навчання, виховання, розвиток), яка виступає як його підсистема, до якої входять об'єкт і суб'єкт педагогічної діяльності, її цільовий, змістовий, операційно-діяльнісний і оціннорезультативний компоненти (Гонеев, 2001).

У якості робочого визначення цього терміна, з педагогічного погляду, Т. Рублевою запропоновано такий варіант: корекційно-педагогічна діяльність - це планований і особливим чином організований педагогічний процес, який реалізується з групами підлітків, що мають незначні відхилення в розвитку й девіації в поведінці, і спрямований на виправлення і реконструкцію індивідуальних якостей особистості та недоліків поведінки, створення необхідних умов для ії формування та розвитку, що сприяє повноцінній інтеграції підлітків у соціум (Рублева, 2002, с. 46).

Для забезпечення комплексного корекційного впливу на дитину з особливими освітніми потребами доцільним $\epsilon$ створення міждисциплінарної команди, яка об'єднуватиме освітян, корекційних фахівців, медиків та батьків для формування ефективного та безперервного освітньо-реабілітаційного простору. Члени міждисциплінарної команди забезпечать реабілітаційно-оздоровчий супровід дитини впродовж всього підготовчого періоду до школи та протягом молодшого шкільного віку: логопед коригує мовленнєвий розвиток, який дозволить дитині спілкуватися з однолітками; педагог здійснює навчально-виховний, навчально-корекційний вплив; реабілітолог забезпечує встановлення можливостей і шляхів компенсації порушень різної складності, виявлення механізмів корекції вторинних відхилень, розвиток навичок самообслуговування, корекційно-розвивальний та реабілітаційно-оздоровчий процес; завданням психолога $\epsilon$ розвиток комунікативної сфери, формування позитивних рис особистості, адекватної самооцінки й необхідного рівня домагань (Білан, 2018, с. 61). 
Відповідно до індивідуальної програми реабілітації дитини 3 інвалідністю (за наявності), команда супроводу складає індивідуальну програму розвитку дитини з особливими освітніми потребами впродовж 2х тижнів з моменту початку освітнього процесу (Гордійчук, 2015).

Одним із шляхів реалізації вищевказаних завдань $\epsilon$ інклюзивне навчання, яке розглядається перш за все як засіб інклюзивної освіти.

Інклюзія - термін, що використовується для опису процесу навчання дітей із особливими освітніми потребами (Дитяткина, 2016, с. 23); це підхід і філософія, яка передбачає, що всі учні (з інвалідністю, без інвалідності) отримують більше можливостей і в плані соціальному, і в плані навчання (Шумиловская, 2011, с. 17); це політика та процес, який дає змогу всім дітям брати участь у всіх програмах (Колупаєва та Савчук, 2011, с. 8).

Завдяки інклюзії відбувається зниження ізоляції й відчуження дитини, вона стає більш активною, перестає відчувати свою «особливість». Саме різноманіття, несхожість учнів один на одного виступає в якості потужного потенційного ресурсу, що сприяє розвиткові і прояву творчого початку (Ахметова та ін., 2013, с. 11).

Основна перевага інклюзивної підходу в навчанні - це створення гнучкого освітнього середовища, яке задовольняє кожну дитину, що відповідає індивідуальним і інтелектуальним, фізичним і психологічним потребам (Далингер, 2017, с. 28).

Інклюзивне навчання реалізує забезпечення рівного доступу до здобуття того чи іншого виду освіти, і створення необхідних умов для досягнення адаптації освіти всіма без винятку дітьми незалежно від їх індивідуальних особливостей, навчальних досягнень, рідної мови, культури, їх психічних і фізичних можливостей (Гусева, 2010, с. 3).

В основу інклюзивного навчання покладено ідеологію, що виключає будь-яку дискримінацію дітей, забезпечує однакове ставлення до всіх людей, але створює особливі умови для дітей, які мають особливі освітні потреби. Потрібно розуміти, що не діти зазнають невдачі, а система виключає дітей. Інклюзивне навчання може підтримати таких дітей у навчанні й досягненні успіху, що дасть шанси і можливості для кращого життя (Шумиловская, 2011, с. 16).

Професійна підготовка педагогічних кадрів для інклюзивної освіти, як вважає Н. Малярчук, $€$ динамічною системою з відносною автономією складових ії суб'єктів. Автор вважає, що для досягнення успішності професійної підготовки необхідні нові педагогічні моделі, що відображають сучасні вимоги до рівня готовності педагога, який реалізує інклюзивну практику (Малярчук та Волосникова, 2015, с. 253).

Висновки та перспективи подальших наукових розвідок. Отже, на основі аналізу понять «інвалідність», «непрацездатність», «особливі потреби дітей», «порушення розвитку», «дезадаптація», «діти групи ризику», 
«проблемні діти», «діти з аномальним розвитком», «діти з інвалідністю», «діти з обмеженими можливостями», «особливі діти», «виняткові діти» уточнено терміни «діти з особливими освітніми потребами», «інклюзивне навчання». Для розкриття ключового поняття «підготовка майбутніх учителівреабілітологів до роботи в умовах інклюзивного навчання учнів загальноосвітніх навчальних закладів» розкрито сутність дотичних понять: «корекційно-педагогічна діяльність», «реабілітаційно-педагогічна діяльність».

Перспективу подальших досліджень вбачаємо в розкритті ієрархії понять «корекційно-реабілітаційна діяльність» та «реабілітаційнопедагогічна діяльність».

\section{ЛІТЕРАТУРА}

Ахметова, Д. 3., Нигматов, 3. Г., Челнокова, Т. А. (2013). Педагогика и психология инклюзивного образования. Казань: Познание (Akhmetova, D. Z., Nigmatov, Z. G., Chelnokova, T. A. (2013). Pedagogy and psychology of inclusive education. Kazan: Knowledge).

Білан, В. А. (2018). Сутність та специфіка корекційно-педагогічної праці дефектолога. Інноваційна педагогіка, 3, 60-64 (Bilan, V. A. (2018). The essence and specificity of correction and pedagogical work of the defectologist. Innovative pedagogy, 3, 60-64).

Бриндіков, Ю. Л. (2017). Реабілітація як сфера професійної діяльності майбутніх фахівців соціальної сфери. Оновлення змісту, форм та методів навчання і виховання в закладах освіти, 17, 106-110 (Bryndikov, Yu. L. (2017). Rehabilitation as a sphere of professional activity of future specialists in the social sphere. Updating the content, forms and methods of education and training in education institutions, 17, 106-110).

Восстановление трудоспособности (1969). Хроника ВОЗ, Т. 23, 255-256 (Disability recovery (1969). Chronicle, Vol. 23, 255-256).

Гарашкина, Н.В.(2006). Новые подходы к реабилитации и социализации детей с ограниченными возможностями. Гаудеамус, 2, 26-32 (Garashkina, N. V. (2006). New approaches to rehabilitation and socialization of children with disabilities. Gaudeamus, 2, 26-32).

Глушко, Е. Г. (2004). Подготовка будущих учителей к коррекционной работе с учащимися в условиях педагогического колледжа (дис. ... канд. пед. наук). Ростов-на-Дону (Glushko, E. G. (2004). Preparation of future teachers for correctional work with students in the conditions of a pedagogical college (PhD thesis). Rostov-on-Don).

Гордеева, А. В. (2002). Реабилитационная педагогика в общеобразовательном контексте (дис. ... доктора пед. наук). Великий Новгород (Gordeeva, A. V. (2002). Rehabilitation pedagogy in a general educational context (DSc thesis). Velikyi Novgorod).

Гонеев, А. Д. (2001). Подготовка учителя $к$ коррекционно-педагогчческой деятельности с подростками (дис. ... доктора пед. наук). Курск (Goneev, A. D. (2001). Teacher preparation for correctional and pedagogical activities with adolescents (DSc thesis). Kursk).

Гордійчук, О.Є. (2015). Міждисциплінарний підхід як невід'ємна умова інклюзивної діяльності. Science and Education a New Dimension. Pedagogy and Psychology, Vol. 31, Is. 61, 25-28 (Hordiichuk, A. E. (2015). An interdisciplinary approach as an indispensable condition for inclusive activity. Science and Education a New Dimension. Pedagogy and Psychology, Vol. 31, Is. 61, 25-28). 
Городова, Т. В. (2011). Управление формированием реабилитационного пространства детей с ограниченными возможностями (дис. ... канд. социол. наук). Белгород (Gorodova, T. V. (2011). M anagement of the formation of the rehabilitation space for children with disabilities (PhD thesis). Belgorod).

Гусева, Т. Н. (2010). Инклюзивное образование как путь развития и гуманизации общества. Инклюзивное образование, 1, 3-5 (Guseva, T. N. (2010). Inclusive education as a way of development and humanization of society. Inclusive education, 1, 3-5).

Далингер, В.А. (2017). Подготовка будущих педагогов к профессиональной деятельности в услових инклюзивного образования. Международный журнал экспериментального образования, 2, 27-30 (Dalinger, V. A. (2017). Preparing future teachers for professional work in inclusive education. International Journal of Experimental Education, 2, 27-30).

Дитяткина, И. А. (2016). Инклюзивное образование: теоретические аспекты. Инклюзивное образование: теория и практика: сб. материалов междунар. науч.-практ. конф. (Орехово-Зуево, 9-10 июня 2016 г.). Орехово-Зуево: Редакционно-издательский отдел ГГтУ, сc. 21-26 (Ditiatkina, I. A. (2016). Inclusive education: theoretical aspects. Inclusive Education: Theory and Practice: Proceedings of international scientific-practical conf. (Orekhovo-Zuievo, June 9-10, 2016). Orekhovo-Zuievo: Editorial and Publishing Department of GSTU, pp. 21-26).

Єжова, Т. Є. (2013). Соціальна реабілітація дітей з інвалідністю. Соціальна педагогіка. Київ: Академвидав (Ezhova, Т. Yе. (2013). Social rehabilitation of children with disabilities. Social pedagogy. Kyiv: Academy).

Колупаєва, А. А., Савчук, Л. О. (2011). Діти з особливими потребами та організація їх навчання. Київ: АТОпоЛ (Kolupaieva, A. A., Savchuk, L. O. (2011). Children with special needs and organization of their education. Kyiv: ATOPOL).

Малярчук, Н. Н., Волосникова, Л. М. (2015). Готовность педагогов к работе в условиях инклюзивного образования. Вестник Тюменского государственного университета. Гуманитарные исследования. Humanitates, T. 1, № 4, 251-267 (Maliarchuk, N. N., Volosnikova, L. M. (2015), Teachers' readiness to work in inclusive education. Bulletin of Tyumen State University. Humanitarian studies. Humanitates, Vol. 1, No. 4, 251-267).

Реабилитация. Словарь основных терминов: Пособие для специалистов в области реабилитации больных и инвалидов (1997). Санкт-Петербург: Турусел (Rehabilitation. Glossary of Basic Terms: A guide for specialists in the field of rehabilitation of patients and the disabled (1997). St. Petersburg: Turusel).

Рублева, Т.В. (2002). Подготовка студентов педагогического вуза к работе в специальных классах общеобразовательной школы (дис. ... канд. пед. наук). Тобольск (Rubleva, T. V. (2002). Preparation of students of a pedagogical university for work in special classes of a comprehensive school (PhD thesis). Tobolsk).

Тимофеева, И. В. (2004). Комплексная реабилитация детей с ограниченными возможностями здоровья (инвалидов) в условиях специализированной школы (дис. ... канд. пед. наук). Екатеринбург (Timofieieva, I. V. (2004). Complex rehabilitation of children with disabilities (disabled) in a specialized school (PhD thesis). Yekaterinburg).

Фабро, І. М. (2010). Реабілітаційна педагогіка: етимологія поняття і генезис науковопедагогічного напряму. Педагогіка, психологія та медико-біологічні проблеми фрізичного виховання і спорту, 9, 105-107 (Fabro, I. M. (2010). Rehabilitation pedagogy: the etymology of the concept and genesis of the scientific and pedagogical direction. Pedagogy, psychology and medical and biological problems of physical education and sports, 9, 105-107). 
Федина, Л. В. (2002). Организационно-педагогические условия формирования готовности учителя $\kappa$ реабилитационной деятельности в системе повышения квалификации (дис. ... канд. пед. наук). Тобольск (Fedina, L. V. (2002). Organizational and pedagogical conditions of forming teacher's readiness for rehabilitation activities in the system of advanced training (PhD thesis). Tobolsk).

Хафизуллина, И.Н. (2008). Формирование инклюзивной компетентности будущих учителей в процессе профессиональной подготовки (дис. ... канд. пед. наук). Астрахань (Hafizullina, I. N. (2008). Formation of inclusive competence of future teachers in the process of vocational training (PhD thesis). Astrakhan).

Шумиловская, Ю. В. (2011). Подготовка будущего учителя к работе с учащимися в условиях инклюзивного образования (дис. ... канд. пед. наук). Шуя Shumilovskaia, Yu. V. (2011). Preparing the future teacher for work with students in the context of inclusive education (PhD thesis). Shuia).

\section{PEЗЮME}

Чередник Анна. Подготовка будущих учителей-реабилитологов к работе в условиях инклюзивного обучения учащихся: категориальный апарат.

В статье предпринята попытка уточнить категориальный аппарат исследования. На основе анализа понятий «инвалидность», «нетрудоспособность», «особые потребности детей», «нарушение развития», «дезадаптация», «дети группы риска», «проблемные дети», «дети с аномальным развитием», «дети с инвалидностью», «дети с ограниченными возможностями», «особые дети», «исключительные дети» уточнено термины «дети с особыми образовательными потребностями», «инклюзивное обучение». Для раскрытия ключевого понятия "подготовка будущих учителей-реабилитологов к работе в условиях инклюзивного обучения учащихся общеобразовательных учебных заведений» раскрыта сущность касающихя понятий: «коррекционно-педагогическая деятельность», «реабилитационно-педагогическая деятельность».

Ключевые слова: дезадаптация, дети группы риска, дети с инвалидностью, дети с ограниченными возможностями, дети с особыми образовательными потребностями, инклюзивное обучение, подготовка будущих учителейреабилитологов.

\section{SUMMARY}

Cherednyk Anna. Preparation of future rehabilitation specialists for work in the conditions of inclusive students' training: categorial apparatus.

The article attempts to clarify the categorical apparatus of the study. Based on the analysis of the concepts of "disability", "special needs of children", "developmental disabilities", "children at risk", "problem children", "children with abnormal development", "children with disabilities", "special children", "exceptional children" the terms "children with special educational needs", "inclusive education" are specified. It is proved that "children with special educational needs" are children with developmental disabilities, which results in the limitation of opportunities for their participation in the traditional educational process, which causes them special needs for specialized pedagogical help, which allows to overcome these limitations and difficulties. The conditions for successful rehabilitation of children with special educational needs are determined.

Inclusive education has been found to include creation of special conditions (a set of individual curricula, plans, methodological materials, literature) and adequate external conditions (required level of comfort, specialized means of transportation and organization of 
adaptive learning places, distance learning, innovative methods and educational communication technology) for children with special educational needs in order to adapt to their needs.

In order to reveal the key concept "preparation of future rehabilitation teachers to work in the conditions of inclusive education of students of secondary schools", the essence of the relevant concepts: "corrective-pedagogical activity", "rehabilitation-pedagogical activity" is disclosed. It is established that preparation of future rehabilitation teachers to work in the conditions of inclusive education of students of general education institutions is a process of complex organization of educational influences aimed at forming a positive attitude to the pedagogical profession, mastering the system of views, beliefs, theoretical concepts of special educational needs needed to master the ways and techniques of working with these students in inclusive learning, and unique personal qualities that provide lasting motivation for this activity.

Key words maladaptation, children at risk, children with disabilities, children with special educational needs, inclusive education, training of future rehabilitation teachers. 